\title{
OBSERVASI LATIHAN RELAKSASI NAFAS PADA PASIEN CHRONIC KIDNEY DISEASES DENGAN FATIGUE
}

\author{
Sri Elis Rohaeti ${ }^{1}$, Andi Sutandi ${ }^{1}$, Eka Afrima Sari ${ }^{1}$, Sri Hartati Pratiwi ${ }^{1}$, \\ Hesti Platini $^{1}$, Hamidah ${ }^{2}$ \\ ${ }^{1}$ Fakultas Keperawatan, Universitas Padjajaran, Bandung, Indonesia \\ ${ }^{2}$ RSUP Dr. Hasan Sadikin, Bandung, Indonesia \\ E-mail:*srielisrohaeti@gmail.com
}

\begin{abstract}
Abstrak
Menilai fatigue merupakan hal yang sangat penting karena fatigue sering meningkat secara langsung setelah dialysis.Masalah akan timbul jika fatigue pada pasien CKD tidak teratasi salah satunya adalah kualitas hidup yang buruk. Latihan nafas adalah teknik alami merupakan bagian strategi holistik self care untuk mengatasi keluhan seperti fatigue. Menggunakan teknik pernafasan yang efektif untuk menurunkan tingkat fatigue dapat menjadi manajemen fatigue yang dapat ditawarkan pada pasien CKD. Studi kasus ini bertujuan untuk mengobservasi penggunaan latihan nafas untuk mengatasi fatigue pada pasien CKD di Ruang Fresia 2 RSUP Dr.Hasan Sadikin Bandung. Penelitian dilakukan dengan pendekatan studi kasus pada 3 orang pasien dengan kriteria: pasien CKD stadium 5 dengan usia $>18$ tahun, menjalani hemodialisis kurang dari 1 tahun, yang mengalami fatigue, dan lama rawat inap minimal 3 hari. Ketiga pasien mengalami fatigue dengan skor rata-rata fatigue hari pertama sebelum latihan relaksasi nafas 59.6 dan skor rata-rata setelah latihan relaksasi nafas adalah 55.6, skor rata-rata fatigue hari kedua sebelum latihan 54.6 dan setelah latihan 49, terdapat penurunan skor rata-rata setelah pasien mempraktikan latihan nafas pada hari pertama dan kedua. Hasil latihan relaksasi nafas yang dilakukan pasien dapat menurunkan level fatigue yang dirasakan pasien.
\end{abstract}

Kata kunci: CKD; fatigue; latihan relaksasi nafas

\begin{abstract}
Breathing relaxation observation in chronic kidney diseases patients with fatigue. Assessing fatigue is very important because fatigue often increases directly after dialysis. Problems will arise if fatigue in CKD patients is not resolved, one of which is poor quality of life. Breath training is a natural technique that is part of a holistic self care strategy to deal with complaints such as fatigue. Using effective breathing techniques to reduce the level of fatigue can be a management of fatigue that can be offered to CKD patients. This case study aims to observe the use of breathing exercises to overcome fatigue in CKD patients in Fresia Room 2 Dr.Hasan Sadikin Hospital Bandung. The study was conducted with a case study approach on 3 patients with criteria: stage 5 CKD patients $>18$ years old, undergoing hemodialysis less than 1 year, who experienced fatigue, and a minimum stay of 3 days. All three patients experienced fatigue with an average score of fatigue the first day before breathing relaxation exercise 59.6 and the average score after breathing relaxation exercise was 55.6, the average score of fatigue the second day before exercise 54.6 and after exercise 49, there was a decrease in the average score after the patient practices breathing exercises on the first and second day. Conclusion: The results of breathing relaxation exercises by the patient can reduce the level of fatigue that is felt by the patient.
\end{abstract}

Keywords: $C K D$, fatigue, breathing relaxation exercise 


\section{Pendahuluan}

Chronic Kidney Diseases (CKD) merupakan masalah kesehatan masyarakat global dengan prevalensi dan insidensi gagal ginjal semakin meningkat, prognosis buruk dan biaya tinggi. Penyakit Ginjal Kronik adalah setiap kerusakan ginjal atau penurunan laju filtrasi glomerulus (LFG) $<60$ $\mathrm{ml} / \mathrm{menit} / 1,73 \mathrm{~m} 2$ untuk jangka waktu $\geq$ 3 bulan. Penyakit ginjal kronis stadium 5 atau dikenal dengan End Stage Renal Diseases (ESRD) adalah kerusakan ginjal atau penurunan laju filtrasi glomerulus (LFG) < 15 $\mathrm{ml} / \mathrm{menit} / 1,73 \mathrm{~m} 2$ (National Kidney Foundation, 2002 dalam Kallenbach, 2012). Diperkirakan 2,6 juta orang di seluruh dunia menerima perawatan dialisis untuk penyakit ginjal stadium akhir pada tahun 2010, dan peningkatan dua kali lipat diperkirakan terjadi pada tahun 2030 (Ghimire et al, 2017). Peningkatan CKD tidak hanya terjadi didunia tetapi juga di Indonesia. Hasil survei yang dilakukan oleh Perhimpunan Nefrologi Indonesia (Pernefri) diperkirakan ada sekitar $12,5 \%$ dari populasi atau sebesar 25 juta penduduk Indonesia mengalami penurunan fungsi ginjal.

Menurut data Kidney Dialysis Outcome Quality Improvement (KDOQI) tahun 2015 pasien CKD mengalami beberapa gejala yang sering terjadi antara lain fatigue, letargi, disfungsi kognitif, pruritus, gangguan tidur, anoreksia dan mual, kram kaki serta gejala depresi (Cabrera, Hansson, Kliger, \& Finkelstein, 2017). Prevalensi fatigue cukup tinggi pada pasien CKD yang menjalani hemodialisis yaitu sekitar 44,7 - 97\%. Fatigue didefinisikan sebagai perasaan fatigue luar biasa subyektif saat istirahat, fatigue dengan aktivitas, kekurangan energi itu menghambat tugas sehari-hari, kurangnya daya tahan, atau kehilangan kekuatan yang dapat menjadi tidak menyenangkan, menyusahkan, dan dapat mengganggu aktivitas fisik dan sosial (Davey, Webel, Sehgal, Voss, \& Huml, 2019).

Fatigue yang tidak diobati dapat berdampak pada kualitas hidup, mengarah pada kelemahan meningkatnya ketergantungan pada orang lain, penurunan energi fisik dan mental, penarikan sosial, dan depresi. Empat gejala yang terkait dengan kualitas hidup yang lebih buruk, antara lain adalah fatigue, nyeri, sesak napas, dan kurangnya kesejahteraan/ well being. Keparahan fatigue pada individu dengan CKD yang menjalani pengobatan hemodialisa adalah salah satu yang tertinggi di antara individu dengan kondisi kronis, termasuk pasien dengan kanker yang menjalani perawatan kemoterapi, pasien dengan depresi, dan pasien dengan Systemic Lupus Erythematosus (Davey et al., 2019).

Beberapa faktor mempengaruhi tingkat fatigue pasien $\mathrm{CKD}$, faktorfaktor yang mempengaruhi fatigue pada pasien CKD adalah : durasi dialisis, adekuasi dialisis, modalitas dialisis, komorbiditas, meningkatnya BMI, level pendidikan yang rendah, dukungan sosial yang kurang, depresi, cemas, malnutrisi, kualitas tidur, turunnya nilai albumin, C-reactive protein Ketika menilai fatigue sangat penting untuk diingat karena fatigue sering meningkat secara langsung setelah dialisis, tetapi dapat berkurang seiring berjalannya waktu (Davey et al., 2019).

Latihan nafas adalah teknik alami merupakan bagian strategi holistik self care untuk mengatasi berbagai keluhan seperti fatigue, nyeri, gangguan tidur, stres dan cemas. Secara fisiologi latihan nafas akan mensimulasi sistem saraf simpatik sehingga meningkatkan produksi endorprin, menurunkan HR, ekspansi paru sehingga berkembang maksimal dan otot-otot menjadi tenang. 
Penelitian yang dilakukan oleh Stanley et al (2019), dari 94 pasien yang melakukan latihan teknik pernafasan menunjukkan manfaat subjektif yang jelas untuk mengoptimalkan pola pernapasan alami, mayoritas pasien (53\%) menggunakan teknik relaksasi dan merasakan penurunan yang cukup besar dalam tingkat kecemasan yang dirasakan. Dalam studi percontohan ini, $27 \%$ pasien menyatakan tingkat fatigue menurun dan energi mereka meningkat saat menggunakan teknik pernapasan sederhana Dua belas persen (12\%) melaporkan peningkatan tidur dan bangun lebih segar pada hari-hari setelah dialisis ketika teknik pernapasan digunakan pada hari sebelumnya.

Penelitian efek breathing exercise pada 60 pasien COPD yang dilakukan 4 kali perhari selama 10 hari terhadap level fatigue. Hasilnya adalah terdapat perbedaan yang signifikan dari level fatigue antara kelompok eksperimen dengan kelompok control dengan nilai $\mathrm{p} 0.001$. Terdapat hubungan antara level fatigue dengan breathing exercise, makin sering exercise dilakukan akan makin menurunkan level fatigue (Khoshkesht, 2011).

Berdasarkan hasil observasi di ruang Fresia 2 RSUP dr. Hasan Sadikin Bandung, teknik pernafasan merupakan intervensi keperawatan yang digunakan oleh perawat untuk mengatasi berbagai masalah pasien seperti pada pasien yang mengalami nyeri dan sesak. Menggunakan teknik pernafasan yang efektif untuk menurunkan tingkat fatigue dapat menjadi manajemen fatigue yang dapat ditawarkan pada pasien CKD. Teknik fisiologis yang sederhana dan praktis, seperti pernapasan panjang, adalah selalu tersedia tanpa biaya dan tanpa risiko bagi pasien dan staf, menawarkan alternatif fisiologis alami untuk meningkatkan kesejahteraan dan kualitas hidup dalam populasi pasien CKD terutama yang menjalani hemodalisis. Oleh karena itu penulis merasa tertarik untuk melakukan studi kasus terkait manajemen fatigue : latihan relaksasi nafas pada pasien CKD yang mengalami fatigue.

\section{Metode Penelitian}

Metode penelitian yang digunakan adalah rancangan penelitian studi kasus. Studi kasus merupakan rancangan penelitian yang mencakup pengkajian satu unit penelitian secara intensif misal klien, keluarga, kelompok, komunitas atau institusi. Rancangan dari suatu studi kasus bergantung pada keadaan kasus namun tetap mempertimbangkan faktor penelitian waktu. Keuntungan yang paling besar dari rancangan ini adalah pengkajian secara terperinci meskipun jumlah responden sedikit, sehingga akan didapatkan gambaran unit subjek secara jelas (Nursalam, 2016).

Studi kasus ini tetap mempertahankan kaidah etik penelitian seperti autonomy dengan menghargai pilihan pasien, beneficience dengan meminimalkan bahaya dan memaksimalkan manfaat, justice dengan memperlakukan semua pasien dengan adil dan pasien tetap diberikan informed consent sebelum melakukan latihan. Tujuan studi kasus ini untuk memberikan gambaran tentang penggunaan latihan nafas untuk mengatasi fatigue pada pasien CKD di Ruang Fresia 2 RSUP Dr.Hasan Sadikin Bandung yang dilakukan rata-rata selama 3 hari kepada setiap pasien dalam rentang waktu perawatan tanggal 20 November sampai dengan tanggal 3 Desember 2019, dengan kriteria inklusi pasien CKD stadium 5 usia > 18 tahun, menjalani hemodialisis kurang dari 1 tahun, mengalami fatigue, rawat inap minimal 3 hari. Fatigue akan diukur menggunakan instrumen Fatigue Severity Scale (FSS). 


\section{Hasil Penelitian Pasien 1}

Pasien pertama adalah Tn. A F, seorang laki-laki berusia 60 tahun dengan diagnosa medis CKD stgae $\mathrm{V}$, sudah menjalani hemodialisis rutin selama 7 bulan dengan akses vaskuler di tangan kanan, datang ke RS untuk menjalani hemodialisa rutin sesuai jadwal 2x/minggu setiap hari senin kamis, namun karena mengeluh sesak dan hasil pemeriksaan rontgen paru ditemukan cairan pada paru kanan, maka pasien dirawat di ruang fresia 2. Pasien sudah menderita diabetes selama 17 tahun dan hipertensi. Berdasarkan hasil wawancara sebelum sering di cuci darah, pasien adalah seorang pemuka agama yang aktif melakukan kegiatan di masyarakat meskipun penderita diabetes dan hipertensi pasien rutin mengkonsumsi obat sesuai saran dokter sehingga tetap dapat beraktivitas, namun sejak menjalani hemodialisis pasien sering mengeluh fatigue, badan terasa lemas, pegal tidak bertenaga sehingga tidak dapat melakukan aktivitas seharihari bahkan untuk makan pun pasien mengatakan terasa capek apalagi harus melakukan kegiatan di luar rumah sehingga sekarang tidak pernah lagi beraktivitas sosial dan lebih banyak diam di rumah.

Dengan menggunakan instrumen Fatigue Severity Scale (FSS) penulis mengkaji derajat keparahan gejala fatigue yang dialami pasien dengan memberikan 9 pertanyaan yang mencerminkan kondisi pasien selama seminggu terakhir dan seberapa sesuai atau seberapa tidak sesuai pernyataanpernyataan dalam instrumen dengan kondisi yang dirasakan oleh pasien. Didapatkan hasil FSS dengan total skor 59, skor tersebut menunjukan pasien mengalami fatigue atau tingkat keparahan fatigue signifikan dengan TD : 160/90 mmhg, N : 90 x/menit, RR : 16. Setelah tingkat fatigue diukur, pasien diberikan edukasi tentang manajemen fatigue dengan latihan relaksasi nafas, pasien dilatih untuk mempraktikan latihan nafas, kemudian penulis mengukur ulang skor fatigue setelah pasien dibimbing melakukan latihan relaksasi nafas didapatkan skor setelah latihan sebesar 52, dengan TD :150/90 mmhg, N:88x/menit, RR : 16.

Pada hari kedua, pasien diminta untuk melakukan lagi latihan relaksasi napas yang telah diajarkan pada hari pertama, sebelum intervensi didapatkan skor fatigue 53, TD : 150/90 mmhg, $\mathrm{N}$ : $89 \mathrm{x} /$ menit, RR : 18 dan setelah intervensi didapatkan skor fatigue 44 , TD :140/90 mmhg, $\mathrm{N}: 85 \mathrm{x} / \mathrm{menit}$, RR : 17 dan pasien mengatakan latihan nafas seperti ini sangat diperlukan saat badan mulai lelah karena setelah bernafas pelan dan dalam badan terasa lebih segar dan merasa memiliki energi kembali.

\section{Pasien 2}

Pasien kedua adalah seorang perempuan Ny. S. D penderita CKD stage $\mathrm{V}$ sudah 8 tahun terjadwal rutin hemodialisis $2 \mathrm{x}$ /minggu setiap hari selasa jumat dengan akses vaskuler di tangan kiri, pasien adalah seorang ibu rumah tangga biasa melakukan kegiatan didalam rumah namun semenjak 2 bulan terakhir tidak dapat melakukan aktivitas harian karena cepat lelah dan lemas, saat dilakukan pengkajian hari jumat klien belum dilakukan hemodialisis, pasien datang ke RS dengan keluhan sesak dalam pengobatan TB paru aktif, dirumah sudah 2 bulan menggunakan oksigen, pasien mengalami anemia dengan $\mathrm{Hb} 5.6 \mathrm{mg} / \mathrm{dl}$, hipertensi dengan TD tertinggi 240/100 mmhg. Klien mengeluh lelah dan tidak bertenaga, hasil pengkajian Fatigue Severity Scale (FSS) sebelum latihan relaksasi nafas didapatkan skor 60, TD: 240/100 mmhg, $\mathrm{N}: 100 \mathrm{x} /$ menit, RR : 20x/menit dan setelah intervensi skor FSS adalah 59, 
TD: 200/100 mmhg, $\mathrm{N}$ :98x/menit, RR :18x/menit.

Pada hari kedua, pasien diminta untuk melakukan lagi latihan relaksasi napas yang telah diajarkan pada hari pertama, sebelum intervensi didapatkan skor fatigue 55, TD : 180/100 mmhg, N : $98 \mathrm{x} /$ menit, RR : 18 dan setelah intervensi didapatkan skor fatigue 53, TD : 170/100 mmhg, $\mathrm{N}$ : 96x/menit, RR $: 17$.

\section{Pasien 3}

Pasien ketiga adalah Ny S usia 52 tahun datang ke RS dengan keluhan sesak, dirawat di RS sebanyak 5 kali sampai akhirnya didiagnosa CKD stage $\mathrm{V}$ dan harus menjalani hemodialisis pasien adalah seorang ibu rumah tangga aktivitas harian biasa dilakukan mandiri di rumah namun sejak sering sakit pasien tidak dapat beraktivitas seperti biasanya karena mudah lelah, letih dan capek, karena belum terjadwal pasien belum mempunyai akses vaskuler yang menetap. Selain CKD pasien mengalami asidosis metabolik, hipertensi heart diseases. Pasien tampak tidak berdaya dan lemah mengalami anemia dengan $\mathrm{Hb} 8.2 \mathrm{mg} / \mathrm{dl}$, pasien mengeluh capek dan lelah hanya bisa berbaring di tempat tidur saja untuk bergerak merasa lemas. Hasil skor fatigue FSS hari pertama sebelum latihan nafas 60 , TD :140/80 mmhg, $\mathrm{N}$ : 96 x/menit, RR : 24 x/menit, skor FSS setelah latihan 56, TD : 130/90 mmhg, N :96 x/menit, RR :20 x /menit.

Pada hari kedua, pasien diminta untuk melakukan lagi latihan relaksasi napas yang telah diajarkan pada hari pertama, sebelum intervensi didapatkan skor fatigue 56 , TD : 140/80 mmhg, N : $94 \mathrm{x} /$ menit, RR : 20 dan setelah intervensi didapatkan skor fatigue 50,

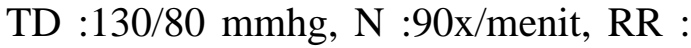
18.
Tabel 1. Skor rata-rata Fatigue

\begin{tabular}{lll}
\hline Skor rata-rata & Hari 1 & Hari 2 \\
\hline $\begin{array}{l}\text { Sebelum } \\
\text { latihan } \\
\text { relaksasi } \\
\text { nafas }\end{array}$ & 59.67 & 54.67 \\
\hline $\begin{array}{l}\text { Setelah } \\
\text { latihan } \\
\text { relaksasi } \\
\text { nafas }\end{array}$ & 55.67 & \\
\hline
\end{tabular}

Ketiga pasien mengalami fatigue dengan skor rata-rata fatigue hari pertama sebelum intervensi latihan relaksasi nafas 59.6 dan skor rata-rata setelah intervensi latihan relaksasi nafas adalah 55.6, skor rata-rata fatigue hari kedua sebelum intervensi 54.6 dan setelah intervensi 49 , terdapat penurunan skor rata-rata setelah pasien mempraktikan latihan relaksasi nafas pada hari pertama dan kedua, menurut Fatigue Severity Scale (FSS) bila skor < 36 tidak mengalami fatigue, skor $\geq 36$ mengalami fatigue. Meskipun terdapat penurunan namun ketiga pasien masih mengalami fatigue.

\section{Pembahasan}

Fatigue didefinisikan sebagai perasaan fatigue luar biasa subyektif saat istirahat, fatigue dengan aktivitas, kekurangan energi yang menghambat tugas sehari-hari, kurangnya daya tahan, atau kehilangan kekuatan yang dapat menjadi tidak menyenangkan, menyusahkan, dan mengganggu aktivitas fisik serta sosial. Fatigue yang tidak diobati dapat berdampak pada kualitas hidup, mengarah pada kelemahan meningkatnya ketergantungan pada orang lain, penurunan energi fisik dan mental, penarikan sosial, dan depresi (O'Sullivan \& McCarthy, 2009 dalam Davey Horvat Christine et al, 2019).

Dalam studi kasus ini terdapat 3 pasien CKD yang masuk dalam kriteria inklusi, dimana 2 orang berjenis kelamin 
perempuan dan 1 orang laki-laki. Ketiga pasien termasuk dalam rentang usia pertengahan dan lanjut usia, penambahan usia mengakibatkan berkurangnya fungsi organ dan bila diiringi dengan penyakit CKD akan mengakibatkan fisik mengalami fatigue. Fatigue merupakan gejala yang sering dialami oleh orang tua (Petchrung, 2004, dalam Sulistini 2012). Studi kasus ini diawali dengan mengkaji sejauh mana pasien mengalami fatigue dengan menggunakan instrumen Fatigue Severity Scale (FSS) ketiga pasien mengalami fatigue dengan skor rata-rata fatigue hari pertama sebelum intervensi latihan relaksasi nafas 59.6 dan skor ratarata setelah intervensi latihan relaksasi nafas adalah 55.6, skor rata-rata fatigue hari kedua sebelum intervensi 54.6 dan setelah intervensi 49 , terdapat penurunan skor rata-rata setelah pasien mempraktikan nafas dalam pada hari pertama dan kedua. Hal ini sejalan dengan penelitian teknik holistik breathing yang dilakukan pada 94 pasien penyakit ginjal terminal yang menjalani hemodialisis selama 6 minggu. Hasilnya $53 \%$ responden mengatakan merasa rileks, $27 \%$ mengatakan fatigue berkurang dan mengalami peningkatan level energi, $12 \%$ kecemasan dan gangguan tidurnya berkurang, pasien merasa lebih segar, dan $8 \%$ mengatakan nyeri/kram saat dialysis berkurang. (Leither \& Sindelir, 2011). Penelitian tentang efek latihan nafas dalam juga dilakukan pada pasien kanker ginekologi yang menjalani kemoterapi adjuvant didapatkan hasil skor fatigue fisik dan skor total untuk kelompok intervensi yang melakukan latihan nafas dalam secara signifikan lebih rendah daripada kelompok kontrol (physical, $\mathrm{P}=0.04$; total $\mathrm{P}=0.04$ ) (Hayama \& Inoue, 2012).

Beberapa penelitian ini menunjukan latihan relaksasi nafas merupakan salah satu manajemen fatigue non farmakologi yang dapat perawat ajarkan pada pasien sehingga pasien mampu mandiri dalam mengelola gejala fatigue yang muncul. Saat kita melakukan latihan nafas dalam, oksigen mengalir ke dalam pembuluh darah dan seluruh jaringan tubuh, membuang racun dan sisa metabolisme yang tidak terpakai, meningkatkan metabolisme dan memproduksi energi. Latihan nafas dalam akan memaksimalkan jumlah oksigen yang masuk dan disuplai ke seluruh jaringan sehingga tubuh dapat memproduksi energi dan menurunkan level fatigue (Brunner \& Suddarth, 2002). Tiga keluhan utama yang dirasakan ketiga pasien saat penulis melakukan wawancara kuesioner salah satunya adalah lelah semua pasien mengatakan lelah merupakan keluhan yang dirasakan oleh pasien meskipun pasien 2 dan 3 mengatakan sesak sebagai keluhan nomer satu namun lelah lebih dirasakan menurunkan semangat untuk beraktivitas dan menyebabkan pasien terbatas dalam melakukan kegiatan di rumah.

Langkah selanjutnya adalah evaluasi bagaimana fatigue tersebut berdampak pada kehidupan sehari-hari karena fatigue bisa sangat melemahkan dan berdampak pada kualitas hidup. Fatigue yang tidak diobati dapat berdampak pada kualitas hidup, mengarah pada kelemahan meningkatnya ketergantungan pada orang lain, penurunan energi fisik dan mental, penarikan sosial, dan depresi (Davey et al., 2019). Dari ketiga pasien masingmasing memiliki aktivitas harian yang berbeda sebagai pemuka agama dan ibu rumah tangga namun ketiga pasien mengatakan semenjak cuci darah sangat mengurangi aktivitas karena mudah lelah, letih dan terikat jadwal cuci darah 2 kali/minggu.

Penyimpangan nilai laboratorium terjadi pada ketiga pasien yaitu penurunan nilai hemoglobin, yang memiliki nilai $\mathrm{Hb}$ paling rendah adalah pasien $2(\mathrm{Hb} 5.6 \mathrm{mg} / \mathrm{dl})$ dan mengalami 
penurunan skor fatigue yang paling sedikit (skor pre 60, skor post 59). Nilai $\mathrm{Hb}$ mengindikasikan terjadinya anemia. Anemia umumnya terjadi pada pasien dengan CKD karena berkurangnya pembentukan erythropoietin dalam membantu pembentukan sel darah merah. Selain itu kadar oksigen rendah karena anemia akan menyebabkan tubuh mengalami fatigue yang ekstrim (fatigue) dan akan memaksa jantung bekerja lebih keras untuk mensuplai oksigen yang dibutuhkan (Black, 2001). Pasien akan mulai merasakan fatigue jika kadar $\mathrm{Hb}$ sebesar 10 gr/dl (Rosenthal, 2008). Meskipun terjadi penurunan nilai ureum setelah hemodialisis pada ketiga pasien tetap nilai ureum masih diatas ambang normal sehingga kondisi uremia ini dapat menyebabkan pasien kehilangan nafsu makan, mual, muntah, kehilangan energi protein dan menurunkan produksi karnitin yang menyebabkan penurunan produksi energi untuk skeletal dan mengakibatkan fatigue (Smeltzar and bare, 2002).

Hasil penelitian tentang faktorfaktor situasional yang mempengaruhi fatigue pada pasien hemodialisis, didapatkan hasil ada hubungan antara frekuensi dan lama menjalani hemodialisis dengan tingkat fatigue (Sulistini \& Yetti, 2012), hal ini sejalan dengan penelitian Ossareh, Roozbeh, Krishnan, Bargman, \& Dimitrios, (2004) bahwa fatigue mulai dialami pasien dialisis rata-rata 6 sampai 8 bulan pertama, fatigue sangat berat dialami pada enam bulan pertama menjalani hemodialisis, masa awal hemodialisis pasien mengalami peningkatan fatigue hal ini bisa dilihat pada pasien 3 merupakan pasien baru dengan lama menjalani hemodialisa 3 bulan dengan skor fatigue yang tinggi yaitu 60, meskipun pasien 2 sudah 8 bulan menjalani hemodialisa namun skor fatigue tetap tinggi hal ini disebabkan fatigue dipengaruhi oleh faktor lainnya seperti penyakit penyerta yang dialami oleh pasien 2 lebih kompleks dimana pasien merupakan penderita TB paru aktif baru terdiagnosa sekitar 2 bulan, hipertensi urgensi, anemia disertai perdarahan dengan $\mathrm{Hb} \quad 5.6 \mathrm{mg} / \mathrm{dl}$. Beberapa faktor mempengaruhi fatigue pada pasien hemodialisis salah satunya komorbiditas atau penyakit penyerta pada pasien. Pasien hemodialisis diketahui memiliki tingkat fatigue yang lebih tinggi ketika mereka memiliki komorbiditas karena akan menambah beban pasien (Campbell, 2017).

Ketiga pasien memiliki riwayat hipertensi dimana hipertensi merupakan faktor penyebab paling umum seperti halnya diabetes. proses pengaturan di ginjal terganggu ketika tekanan darah sistemik tetap meningkat selama periode waktu yang lama, seperti hipertensi yang tidak diobati. Pertama, hipertensi yang tidak diobati menyebabkan kerusakan pada pembuluh darah, menebal dan kuat untuk menahan tekanan yang meningkat. Pembuluh darah menjadi menyempit secara permanen karena penebalan. Arteri yang memberi makan ginjal menanggapi tekanan sistemik yang tinggi dengan konstriksi, sehingga mengurangi jumlah darah beredar melalui ginjal. Ginjal pada gilirannya menafsirkan ini sebagai defisit dalam aliran darah, sebagai tanggapan, sekresi renin dan aldosteron distimulasi, menyebabkan natrium dan air retensi untuk meningkatkan volume darah, karena ginjal kekurangan perfusi (Horigan, Rocchiccioli, 2012).

\section{Simpulan}

Hasil dari observasi latihan relaksasi nafas yang dilakukan pasien dapat menurunkan level fatigue yang dirasakan pasien. Hal ini terlihat dari respon pasien yang menunjukan rasa nyaman dan adanya penurunan rata-rata skor fatigue hari pertama sebelum latihan relaksasi nafas 59.6 dan skor 
rata-rata setelah latihan relaksasi nafas adalah 55.6, skor rata-rata fatigue hari kedua sebelum latihan 54.6 dan setelah latihan 49.

Mengkaji tingkat fatigue atau fatigue pada pasien CKD merupakan langkah penting yang dapat dilakukan oleh perawat, karena fatigue yang tidak diatasi dapat menurunkan kualitas hidup. Perawat dapat melakukan berbagai manajemen fatigue salah satunya yaitu latihan relaksasi nafas dimana perlu diperhatikan faktor- faktor yang mempengaruhi baik faktor demografi, faktor fisiologis maupun psikologis pasien.

\section{Referensi}

Butarbutar. (2014). Uji Reliabilitas Dan Validitas Fatigue Severity Scale Versi Bahasa Indonesia Pada Dokter Residen RSUP Dr ., 0-10.

Cabrera, V. J., Hansson, J., Kliger, A. S., \& Finkelstein, F. O. (2017). EvidenceBased Nephrology Symptom Management of the Patient with CKD : The Role of Dialysis, 12(3), 687-693.

Campbell, M. L. (2017). Fatigue in Patients with Chronic Kidney Disease : Evidence and Measures. Continuing Nursing Education, 44(4), 337-345.

Davey, C. H., Webel, A. R., Sehgal, A. R., Voss, J. G., \& Huml, A. M. (2019). Fatigue in Individuals with End Stage Renal Disease. Continuing Nursing Education, 46(5).

Ghimire, S., Castelino, R. L., Jose, M. D., \& Zaidi, S. T. R. 2017. Medication adherence perspectives in haemodialysis patients: a qualitative study, $1-9$. https://doi.org/10.1186/s12882-0170583-9

Hayama, Y., \& Inoue, T. (2012). Complementary Therapies in Clinical Practice The effects of deep breathing on ' tension e anxiety' and fatigue in cancer patients undergoing adjuvant chemotherapy.

Complementary
Therapies in Clinical Practice, 18(2), 94-98.

https://doi.org/10.1016/j.ctcp.2011.10.0 01

Horigan, Rocchiccioli, T. (2012). Dialysis and fatigue: Implication for nurses- A Case Study Analysis. NIH Public Access Author, 21(3), 1-12.

Jhamb et al. (2008). Fatigue in Patients Receiving Maintenance Dialysis: A Review of, 52(2), 353-365. https://doi.org/10.1053/j.ajkd.2008.05.0 05

Kallenbach Judith Z. 2012. Review of hemodialysis for nurses and dialysis personnel 8 th ed. Elsevier Mosby

Khoshkesht, S. (2011). The Effect of Breathing exercises on The Fatigue Levels of Patients with Chronic Obstructive Pulmonary Disease, 29-33.

Kim, S., Kim, H., \& Kim, H. (2005). Effects of a relaxation breathing exercise on fatigue in haemopoietic stem cell transplantation patients, (Winningham 1991), 51-55.

Leither, T. W., \& Sindelir, C. (2011). Benefits of a Holistic Breathing, 38(2), 149-153.

Nursalam. (2014). Metodologi Penelitian Ilmu Keperawatan : Pendekatan Praktis, Edisi 3. Jakarta : Salemba Medika

Ossareh, S., Roozbeh, J., Krishnan, M., Bargman, J. M., \& Dimitrios, G. (2004). Fatigue in chronic peritoneal dialysis patients, 535-541.

Rosenthal, T. C. (2008). Fatigue: An Overview. American Family Physician Volume 78, Number 10.

Rosyidi, Kholid. 2013. Prosedur Praktik Keperawatan Jilid 1. Trans Info Media. Jakarta

Sulistini, R., \& Yetti, K. (2012). Faktor faktor yang mempengaruhi Fatigue Pada Pasien yang menjalani Hemodialisis. Jurnal Keperawatan Indonesia Volume 15 No 2 Hal 75-82. 